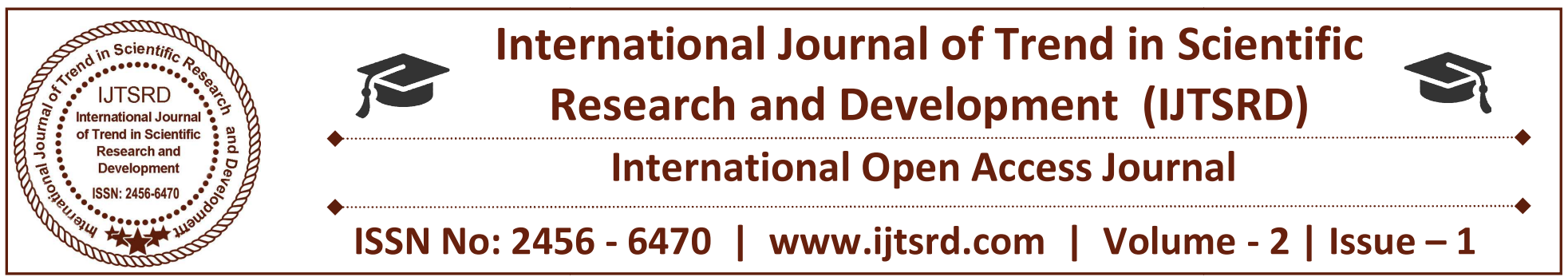

\title{
Water Quality Requirements and Management Strategies for Fish Farming (A Case Study of Ponds around Gurgaon Canal Nuh Palwal)
}

\author{
Warish Khan ${ }^{1}$, Abdul Vahab ${ }^{2}$, Adil Masood ${ }^{3}$, Najib Hasan ${ }^{4}$ \\ ${ }^{1}$ Department of civil engineering, Al-Falah-University, Faridabad, India \\ 2 Department of civil Engineering, MVN University, Palwal, India \\ ${ }^{3}$ Department of civil Engineering, Jamia Millia Islamia, New Delhi, India \\ ${ }^{4}$ Department of civil Engineering, Govt.Polytechnic, Uttawar Palwal, India
}

\section{ABSTRACT}

A study on standard water quality parameter requirements and management strategies suitable for fish farming is presented. The water quality criteria studied based on physical, chemical and biological properties of water include temperature, turbidity, total suspended solids (TSS), total dissolved solid (TDS), nitrate- nitrogen, $\mathrm{pH}$, Dissolved oxygen (DO) biochemical oxygen demand (BOD) and total hardness. Water samples from around Gurgaon Canal in NCR union territerian New Delhi capital of India, were analyzed based on the afore-mentioned criteria to assess its suitability as a source of water for fish farming. The results of the analysis compared with international standards and also Indian standards revealed that the river temperature of $30.70 \mathrm{C}$ fall within the acceptable range for fish farming. However, the $\mathrm{pH}$ of 7.1, total hardness of $470 \mathrm{mg} / \mathrm{l}$, total dissolved solids of $13.60 \mathrm{mg} / \mathrm{l}$ and biochemical oxygen demand of $36 \mathrm{mg} / \mathrm{l}$ all differed slightly from the standard recommended values. This study will aid fish farmers on the necessary treatment needed to effectively use water from this source for fish farming.

Keywords: Water quality criteria, gurgaon canal nuh palwal, biochemical oxygen demand, total suspended and total dissolved solids

\section{INTRODUCTION}

The major environmental issues of our time are the growing concern about the water quality suitable for use by humans and animals (Calamari and Naeve, 1994). It is a known fact that the water quality condition is constantly being threatened by pollution. The discharge of large quantities of wastes has been largely influenced by industrialization, urbanization, population increase and green revolution (Biney et al., 1994). These have resulted in widely distributed sources of pollution and thereafter, have created significant problem on the canal and lakes to assimilate contaminants and increase their pollution loads. Aquaculture can be defined as the rearing of aquatic animals. It is the breeding of fish, crabs and other aquatic organisms in specially designed ponds, to enhance better yield and quality of fish and crabs produced. In the case of fish farming, these ponds are known as fish ponds. In South India, fish and crabs are widely consumed as a remarkable source of animal protein. In Bangali communities of India, fish and crab are more widely consumed than meat. Although fish farming and fish ponds are growing in India, pond fisheries contain the greater source of fish consumption. Pond fisheries also constitute the major occupation of many acres around the gurgaon canal NCR in India. Water as an important natural resource, influences human settlement patterns, agricultural activities and citing of industries (Nwaugo at al., 2006). Incidentally, in wealth generating process, 
water is a victim of dumping of wastes which degrade the water for other uses (Trouba, 2002). Running waters are exploited to supply irrigation and drinking water, generate electricity, and receive wastes (Tucker and Hargreaves, 2008). Attempts aimed at increasing aquaculture yield through pond fertilization practices especially those involving the dumping of domestic, poultry and organic wastes into the culture systems has been found to affect the microbiology and biochemistry of the culture systems (Ogbulie, 1995). The flesh of fish is usually infected with a wide range of microbes present in the water body. These bacteria are often found in the scales, gills, gut and alimentary tract of the fish (Pyatkin and Krivoshein, 1986). The amount of bacteria that exist on the body and internal organs of the fish is indicative of the extent of pollution of the water environment. Furthermore, too many trace elements are mined at a pace that exceeds their natural mobilization rates (Philips, 1991). Also many antropogenically derived metals, pesticides and chemicals, which are regarded as aquatic contaminants have remained in use in both developing and advanced nations of the world (Biney et al., 1994). The overall toxicological impact of this pollution problem is that the fishery productivity suffers after all (Birch et al.,1986). The adverse effect of these organic and in organic pollutants on water quality of fish pond, have led to poor yield of fish from that water bodies. This poor yield is very significant coupled with the ever increasing demand for fish, as a better alternative source of animal protein, compared to meat. This paper therefore determined adequate water quality requirements and other management strategies, suitable for optimum yield of fish in fish farming. The close proximity of the gurgaon canal nuh makes it a water source that could be harnessed for various domestic and agricultural purposes including aquaculture, irrigation farming and bottled water production.

\section{MEASUREMENTS OF WATER QUALITY}

In estimating the quality of water, the physical, chemical and biological properties of the water should be considered. Therefore, physical chemical and biological analyses are required to be done. The physical properties of water normally considered include: temperature, colour, turbidity, odour, taste, total suspended solids and total dissolved solids. Aquatic animals take on the temperature of their environment and are intolerant of rapid temperature fluctuations. Water temperature affects the feeding pattern and growth of fish. Fish generally experience stress and disease breakout when temperature is chronically near the maximum tolerance or fluctuates suddenly. Warm water holds less dissolved oxygen than cool water. This is because every $100 \mathrm{C}$ rise in temperature doubles the rate of metabolism, chemical reaction and oxygen consumption in general. Turbidity and colour of water are closely related. High turbidity, one of the major factors that impede light penetration, could be due to presence of planktonic organisms or clay particles. The chemical properties of water that are of utmost importance in fish farming include: $\mathrm{pH}$, ammonia-nitrogen (NH3$\mathrm{N})$, nitrite- nitrogen ( $\mathrm{NO} 2-\mathrm{N})$, nitrate- nitrogen (NO3-N) and total phosphorous (TP) (Pulatsu, et al., 2004). The biological properties that affect aquaculture include: biological oxygen demand (BOD) and presence of bacteria. The biological oxygen demand is a very important factor in determining water quality suitable for fish farming. During respiration, fish like other animals, take in oxygen and give out carbon IV oxide (CO2), and this fish aerobic metabolism requires dissolved oxygen. The summary of the standard water quality requirements for fish farming is contained in Table 1.

Table 1: Standard Water Quality Requirements for Fish Farming. S/N WATER QUALITY CRITERIA RECOMMENDED VALUE (RANGE) SOURCE

\begin{tabular}{|l|l|l|l|}
\hline \multicolumn{1}{|c|}{ Quality Parameter } & \multicolumn{1}{c|}{ Unit } & \multicolumn{1}{c|}{ Bethod/Instrument } \\
\hline Ph & - & $6.6-8.5$ & Digital $\mathrm{pH}$ meter \\
\hline BOD & $\mathrm{Mg} / 1$ & No mention & 5 days test \\
\hline Temp. & $0 \mathrm{C}$ & $250 \mathrm{C}-300 \mathrm{C}$ FAO & Digital Temp. meter \\
\hline T.D.S & $\mathrm{Mg} / \mathrm{l}$ Devis & 0.13 & Digital T.D.S meter \\
\hline Hardness & $\mathrm{Mg} / 1$ & $50-100$ & EDTA titration method \\
\hline D.O & $\mathrm{Mg} / 1$ & No mention & Azide Modification method \\
\hline Turbudity & $\mathrm{Mg} / 1$ & No mention & Nephelometric method \\
\hline
\end{tabular}




\section{MATERIALS AND METHODS}

\subsection{Sample Collection and Analysis}

In order to obtain raw data needed to carry out this work, ten points A, B, C, D, E, F, G, H, I and J were selected along the length of the gurgaon canal both sides. Sterilized and sealed bottles were used for sample collection at $4 \mathrm{oc}$ with the help of ice cube. The marked sterilized bottles were dipped into the centre of the river, the seals were removed while bottles were still inside the water and the bottles were filled up to fullness, sealed back and covered with black sack with water to avoid solar radiation effect. Plastic containers were also filled with water and the temperature of the river was measured directly inside the river. These procedures were repeated at each sampling location. All parameters tested were grouped under three heading namely: - Physical, chemical and biological. The physical parameters include: temperature, turbidity, total suspended solids and total dissolved solids. The chemical parameters include $\mathrm{pH}$ and Nitrate- Nitrogen (No3-N). The biological parameter includes: Biochemical Oxygen demand.

\subsection{Determination of Physical Properties}

The turbidity of the water sample was tested using a digital turbidity meter and the turbidity value was read out directly in Nephelometric Turbidity Units (N.T.U). The temperature was measured immediately at the exact point of collection using mercury in glass thermometer calibrated in degree Celsius (oC). The total suspended solids and total dissolved solids were determined using standard method of filtration, evaporating to dryness and weighing. The values obtained were expressed in $\mathrm{mg} / \mathrm{l}$.

\subsection{Determination of Chemical Properties}

The $\mathrm{pH}$ values of the samples were determined using digital $\mathrm{pH}$ meter and displayed on the digital dial of the $\mathrm{pH}$ meter at the all locations. The Nitrate Nitrogen (NO3-N) test was done using the Spectrophotometer test, and the result was obtained in $\mathrm{mg}$ of Nitrate per liter sample of water.

\subsection{Determination of Biological Properties}

The Biochemical Oxygen Demand (BOD) was determined using dissolved oxygen meter, incubator and BOD bottles. The BOD bottles were filled with the sample and the dissolved oxygen measured and recorded (D1) with the calibrated (dissolved oxygen meter) before incubating at $200 \mathrm{C}$ for 5 days. The dissolved oxygen was measured after incubation and recorded as (D2). The BOD was calculated using the equation below.

$\operatorname{BOD}(\mathrm{mg} / \mathrm{l})=(\mathrm{D} 1-\mathrm{D} 2) / 0.5$

Where, 0.5 is the dilution factor. The Total Hardness was done using the Eriodrome indicator/ Digital titrator method. The digital titrate required was recorded once the color changed from red to pure blue and the value was multiplied by 2.0 to obtain the $\mathrm{mg} / \mathrm{l}$ total hardness in $\mathrm{CaCo}$.

\section{RESULTS}

The results of water quality tests conducted at Gurgaon canal are summarized in Table 2.

Table 2: Results of water quality tests carried out at various ponds

\begin{tabular}{|l|l|l|l|l|l|l|l|l|l|l|l|l|}
\hline \multicolumn{1}{|c|}{ PARAMETER } & UNIT & \multicolumn{1}{|c|}{ A } & \multicolumn{1}{|c|}{ B } & C & D & E & F & G & H & I & J \\
\hline TEMP & $0 \mathrm{C}$ & 29.1 & 28.7 & 30.5 & 28.6 & 27.5 & 28.8 & 28.6 & 28.4 & 30.1 & 29.4 \\
\hline $\mathrm{Ph}$ & - & 6.4 & 6.4 & 6.3 & 6.8 & 6.3 & 7.1 & 6.9 & 6.6 & 7.2 & 6.3 \\
\hline $\mathrm{D} . \mathrm{O}$ & $\mathrm{Mg} / 1$ & 4.8 & 5.2 & 4.7 & 4.9 & 5.0 & 5.2 & 4.9 & 4.9 & 5.6 & 5.3 \\
\hline BOD & $\mathrm{Mg} / 1$ & 26 & 22 & 34 & 32 & 38 & 34 & 40 & 34 & 30 & 32 \\
\hline TOTAL HARDNESS & $\mathrm{Mg} / 1$ & 420 & 410 & 460 & 450 & 438 & 460 & 430 & 450 & 470 & 430 \\
\hline TURBUDITY & $\mathrm{NTU}$ & 310 & 305 & 290 & 296 & 316 & 270 & 282 & 315 & 306 & 298 \\
\hline T.D.S & $\mathrm{Mg} / 1$ & 670 & 665 & 685 & 710 & 690 & 730 & 708 & 653 & 740 & 726 \\
\hline
\end{tabular}




\subsection{Discussion / Management Strategies}

\subsubsection{Temperature}

The temperature of various ponds around Gurgaon canal was found to be 27.5-31.1 0C. This value falls within the range of $27.60 \mathrm{C}$ to $300 \mathrm{C}$ for optimum yield in aquaculture recommend by FAO (2006). In fish farming heating of the water may be necessary if the temperature of the water falls below the recommended range.

\subsubsection{Total Dissolved Solid}

The value of total dissolved solids of various ponds around Gurgaon canal was found to be is 653-726 $\mathrm{mg} / \mathrm{l}$. This value is far greater than the standard value of $0.13 \mathrm{mg} / \mathrm{l}$ recommended by Davis (1993).This implies that Gurgaon canal should first be treated with chemicals to reduce the quantity of dissolved solids to the acceptable range before it could be used as a source of water for fish farming.

\subsection{4 pH}

The average value of the $\mathrm{pH}$ of various ponds around Gurgaon canal was found to be Gurgaon canal is 5.77.10. This value is slightly lower than the standard range of values of 6.0 - 9.0, recommended by Davis (1993). The $\mathrm{pH}$ is interdependent with other water quality parameters, such as carbon dioxide, alkalinity, and hardness. It can be toxic in itself at a certain level, and also known to influence the toxicity as well of hydrogen sulfide, cyanides, heavy metals, and ammonia (Klontz, 1993). The $\mathrm{pH}$ can also affect fish health. For most freshwater species, a $\mathrm{pH}$ range between 6.5 - 9.0 is ideal, but most marine animals typically cannot tolerate as wide range $\mathrm{pH}$ as freshwater animals, thus the optimum $\mathrm{pH}$ is usually between pH 7.5 and 8.5 (Boyd, 1998). Below pH 6.5, some species experience slow growth (Lloyd, 1992). At lower $\mathrm{pH}$, the organism's ability tomaintain its salt balance is affected (Lloyd, 1992) and reproduction ceases. At approximately $\mathrm{pH} 4.0$ or below and $\mathrm{pH} 11$ or above, most species die (Lawson, 1995). Table 1 shows the effects of different $\mathrm{pH}$ levels to warm water pond fish, while Table 2 shows the recommended value for salmonid aquaculture production.
Table 3: $\mathrm{pH}$ tolerance levels and its effect on pH levels Effects on warm water pond fish

\begin{tabular}{|l|l|}
\hline$<4.0$ & Acid death point \\
\hline $4.0-5.0$ & No production \\
\hline $6.5-9.0$ & $\begin{array}{l}\text { Desirable range for fish } \\
\text { production }\end{array}$ \\
\hline $9.0-11.0$ & Slow growth \\
\hline$>11.0$ & Alkaline death point \\
\hline
\end{tabular}

Source: Lawson 1995, Tarazona and Munoz 1995

\subsubsection{Total Hardness}

The total hardness of of various ponds around Gurgaon canal is found to be is measured as 410-460 $\mathrm{mg} / \mathrm{l}$. This value is more above the standard range of $50-100 \mathrm{mg} / \mathrm{l}$ as recommended by WHO (2003). This implies that the water is too hard, and the amount of water soluble salts it contained is high. To deacrease the hardness of the water to reach the acceptable value, a proper treatment needed. It therefore implies that water $\mathrm{pH}$ (degree of acidity or alkalinity) and water hardness can all be changed by adding lime to the pond as described above.

\subsubsection{Biochemical Oxygen Demand}

The Biochemical Oxygen Demand (BOD) of various ponds around Gurgaon canal is found to be measured as $22-40 \mathrm{mg} / 1$. This value is higher than the standard range of 3-20 mg/l recommended by Boyd (2003). The oxygen content of a river may be affected by such activities as washing and bathing. The BOD of water in fish ponds can be decreased by removing hardness and by keeping the water at optimum temperature. This is because too high a temperature reduces the amount of dissolved oxygen. Over stocking of fish in the pond could be another cause of oxygen shortage.

\subsubsection{Turbidity}

High turbidity of water can decrease fish productivity, as it will reduce light penetration into the water and thus oxygen production by the water plants. Dissolved suspended solids will also clog filters and injure fish gills (Carballo et al., 2008). Carballo et al., (2008), gave a suitable method for reducing turbidity using a silt catchment basin. This is in the form of a small reservoir at the inlet of the pond. The water flows into this reservoir and is kept there until the mud settles on the bottom. Then the clear water is let into the fish pond. Another method to decrease turbidity is to 
apply lime, gypsum or preferably alum at 1 gram per 100 liters of water. However, the only real long term solution to turbidity is to divert muddy water away from the pond and ultimately protect dykes from erosion, which cause the high water turbidity.

\section{CONCLUSION}

The specific objective of this work was to establish water quality requirements and management strategies for fish farming, using various ponds around Gurgaon canal nuh palwal as a case study. Water quality is a measure of the physical chemical and biological properties of the water. It was discovered in the course of the research that optimum yield of fish in fish farming operation is dependent on these properties of water which include: temperature, total suspended solids, total dissolved solids $\mathrm{pH}$, dissolved oxygen, total hardness, biochemical oxygen demand (BOD) nitrate-nitrogen (NO3-N) and turbidity. The analysis carried out various ponds at Gurgaon canal nuh palwal showed that only temperature, TSS, No3$\mathrm{N}$ and turbidity, fell within the accepted range of values for fish farming. This development necessitated the introduction of management strategies and practices which will improve on the water quality and bring it to the acceptable standard, based on other water criteria. Some of the management strategies include: the addition of lime, mechanical aeration, introduction of additives like acidic salts, and incorporation of filters etc.

\section{RECOMMENDATIONS}

Some recommendations presented here are from the results of a previous project, NFDB (National Fishries Development Board of Aquaculture India) and of consultations with the different sectors, i.e. national agencies, state government; aquaculture feed millers, producers, fish farmers and the academe.

\section{Information Campaign}

One problem for low compliance may be due to lack or insufficient information on the effects of pollution to the water environment as well as to the existing laws and guidelines in place. This can be address by including information campaign as part of the water quality monitoring guideline. The religious sector can also be tapped as a medium to transfer the information, as they are proven to be very effective and has power to move the critical mass into action.

\section{Monitoring and Surveillance}

The India government has inadequate staff and resources to regularly and religiously monitor all the monitoring stations in the whole country, as well as conduct visits to all the point sources of effluents. One of the recommendations is the creation of interagency body that will be responsible in the monitoring. The composition is important since there are different sectors involved, e.g. industrial effluents, aquaculture wastes, domestic sewage, etc. One agency alone may not have the technical capabilities or equipments. This is also seen as a good mechanism in addressing the problem of insufficient staff and resources.

\section{Incentive System and Sanctions}

The monitoring system implements the polluter's fee, i.e. the violators pay for the pollution that they produce. In addition to that, an incentive system can also be included to encourage the compliance. One way is the certification program, wherein the industries or aquaculture operators that comply will be awarded a certificate or a seal signifying their compliance. There can also be a reduction on taxes or annual registration fees.

\section{Standards/criteria protecting the Aquaculture Industry}

It is recognized that aquaculture's contribution to food security is significant, and as capture fisheries supply levels off, the demand for fishery products will be supplied by aquaculture. As mentioned earlier, the existing standards and criteria are meant to protect the water body in general, and there are no special provisions protecting the aquaculture industry like in other countries such as New Zealand and Australia.

\section{REFERENCES}

1. Biney, C.; Amuzu, D.; Calamari, N.; Kaba, I.C.; Mbone, H.; Naeve, P.B.; Ochumba, O.; Radegonde, V.; and Saad, M.A. 1994. Review of heavy metals. Committee on Inland fishery Advisory. Caribbean Inland Fishery Association (C I F A). Tech papers 25: 33- 39.

2. Birch, P.B.; Forbes, G.; and Schoffield, N. J. 1986. Monitoring the effects of catchment management practices. Water scientific Technology 18: 53-61. 
3. Boyd, C.E. 2003. Guide lines for aquaculture effluent management at farm-level. Aquaculture, 226: $101-112$.

4. Calamari, D.; and Naeve, H. 1994. Towards Management of the aquatic environment. Caribbean Inland fishery Association (CIFA) Technical papers. 25: 7- 22

5. Carballo, E.; Eer, A.V.; Schie, T.V.; and Hilbrands, A. 2008. Small- Scale fresh water fish farming. Agrodok 15.

6. Davis, J. 1993. Survey of Aquaculture effluents permitting and 1993 standards in the South. Southern Regional Aquaculture Centre, SRAC publication no 465 USA, 4PP.

7. FAO (Food and Agriculture Organization of the United Nations). 2006b. State of World Aquaculture. 2006. FAO Fisheries Technical paper 500. Rome: FAO Fisheries Department.

8. Nwaugo, V.O.; Obiekezie, S.O.; Onyeagba, R.A.; Okereke, J.N.; and Udebuani, A. 2006. The physicochemical investigation of Amicol Lake in Ivo area of Ebonyi State, Nigeria. World Journal of Biotechnology, 7: 1055-1061.

9. Ogbulie, J.N. 1995. Microbial Ecology of Nigerian fish culture systems. PhD Thesis. University of Port Harcourt, Nigeria. 314 pp.
10. Philips, D.J.H. 1991. Selected trace elements and the use of Biomonitors in sub tropical marine ecosystem. Revise Environmental Contaminated Toxicology.120:105-129

11. Pulatsu, S.; Rad, F.; Koksal, G.; Aydin, F.; Benli, A.C.K.; and Topcu, A. 2004. The Impact of Rainbow Trout farm Effluents on water Quality of Karasu stream, Turkey. Turkish Journal of fisheries and Aquatic Sciences. 4: 0915

12. Pyatkin, K.D and Krivoshein, Y.S.1986.Microbiology. MIR publishers, Moscow.167 pp.

13. Schwartz, M.F and Boyd, C.E. 1994. Channel Catfish Pond Effluents. Prog. Fish Cult, 56: 273 281.

14. Trouba, D. 2002: Why balance water use? Journal of Stockholm water front 2:2 Stockholm, Sweden.

15. Tucker, C.S and Hargreaves, J.A. 2008. Environmental Best Management practices for Aquaculture. Blackwell Publishing. U.S.A.

16. WHO (World Health Organization). 2003. Global journal of pure and Applied Science Vol. 4 No. 2. 